\title{
BARRIERS TO USING OF QUINTUPLE HELIX MODEL TO CREATE INNOVATIONS IN POLISH REGIONS
}

\author{
Irena $Ł A C K A$ \\ West Pomeranian University of Technology, Szczecin; irena.lacka@zut.edu.pl, ORCID: 0000-0003-0762-8856
}

Purpose: The main purpose of the paper is to present and discuss the assumptions of the model and indicate whether the regional innovativeness can be improved with the help of multi-branch co-operation oriented so as to form new solutions to contemporary development problems. An additional purpose of the paper is to indicate barriers that hinder the application of this form of co-operation in Polish regions.

Design/methodology/approach: The paper has theoretical and reviewing nature. It was drawn up based on an analysis of the literature on the topic and the results of foreign authors' research along with the information obtained from practicians (management board members of the cluster active in the West Pomeranian region).

Findings: Quintuple Helix model is a concept which explains the principles and effects of co-operation for the improvement of regional innovativeness and development in the conditions of the natural environment challenges and sustainable development. This co-operation is built between regional partners of innovative processes. The experience of highly developed countries shows that such organized cooperation is effective. In Poland, this concept is very rarely used, and its implementation encounters significant barriers.

Practical implications: The presented considerations are important for entities of regional innovative networks. They will gain knowledge of the Quintuple Helix concept in the light of the challenges of the modern world (economic, ecological, demographic, cultural and others). In addition, they learn the essence and scope of barriers to introducing effective innovative cooperation. This will allow them to reduce barriers. In the future, new solutions to problems of the development of society and economy will appear in Polish regions faster.

Originality/value: The added value of the article is the presentation of the Quintuple Helix model as a tool to solve sustainable development problems in the region. This concept is not widely known in Poland, nor used in the mesoscale. This is due to the lack of interdisciplinary research on this issue and very strong barriers to such cooperation. They are found in all elements of this model. Its practical implementation requires their removal. In the article, the author diagnosed and described them.

Keywords: Quintuple Helix model, innovativeness/innovation, region, challenges, barriers. 


\section{Introduction}

In the last decade of the 21st century, the economic growth and development of regions is determined by their innovative capacity and the ability to adapt to the challenges of the modern global economy. These challenges are universal and they influence more or less the development of both highly developed territories and developing countries (Carrayanis, and Campbell, 2014; Kimatu, 2016; Baccarne et al., 2016; Grundel, and Dahlström, 2016; Carayannis et al., 2018). The challenges of the modern economy which enforce the innovation of the national, regional and local economy at a much higher scale than before are the following: globalization, climate change, poverty and growing social inequalities, stormy results of economic crises, demographic and environmental changes, transformations of population and economic systems aimed at greater sustainability, intensive technology development and the necessity to monitor it, ability to generate new solutions in the field of social life (new values and attitudes), economic life (in production, distribution, consumption) and in the sphere of regulation (standards, citizens' freedoms, degree of state interference with social and economic life, economic, social, environmental, innovative and educational policy tools). These challenges set out new solutions and the ability to start cooperation between regional partners of innovative processes.

However, analyzing this problem at the mesoscale of individual states, differences can be noticed in the ability to find answers to these challenges. This is linked to the intensive use of knowledge and technology to create product, process, organizational and marketing innovations, eco-innovations and social innovations (Kondratiuk-Nierodzińska, 2013; Szczepaniak, 2014; Morawska-Jancelewicz, 2016; Marszowski, 2019). Innovative processes are complicated, multidisciplinary, placed in a given space, in the regional and local environment. They require the integration of many different resources, knowledge and knowhow included, which are transferred in the process of learning and teaching (Prystom, 2012). Individual business entities (e.g. entrepreneurs, scientists, local self-government units, support institutions) are not vested with all resources of knowledge, skills, competences, physical and financial capital, social capital and information needed to create innovations. In order to reduce these difficulties, regional authorities are trying to support the creation of a complicated structure based on the cooperation between those, taking part in regional innovation processes. In this way, a specific environment innovation-friendly comes into being. Various theoretical concepts of the regional innovation system, regional innovation networks and Triple, Quadruple and Quintuple Helix models explain its effectiveness in improving the innovation and competitiveness of the region. The latter two models attempt to explain in the most comprehensive way how regional innovations originate, are implemented and diffused in consequence of the impact of modern economy challenges on innovation processes and their participants. Highly developed countries and those recognized as innovation leaders, have been 
putting these concepts into life for years, and their results confirm the effectiveness of regional innovative cooperation under helix models. They are very rarely used in Polish regions. Neither are they the subject of intensive research on the conditions for this form of cooperation, its results and methods applied to measure effects. In Poland, establishing cooperation under the helix models (in particular, the Quintuple Helix model) encounters significant barriers. They make difficult the effectiveness of actions aimed at creating and putting into life new solutions to improve competitiveness and development of regions in the modern knowledgebased economy.

The purpose of the article is to present the Quintuple Helix model and discuss its capabilities to support the sustainable development of regions in Poland. Its additional goal is to identify barriers that hamper its use in Polish socio-economic reality. The following theses were formulated in the study:

- the Quintuple Helix model is a theoretical concept appropriate to form the principles for the cooperation of regional partners so as to solve sustainable development problems,

- in Poland, practical cooperation under the Quintuple Helix model is hampered by various barriers which underlay all areas which take part in building innovative networks.

To achieve the indicated goals, it required an analysis of the rich literature on the subject dedicated to regional innovation systems, problems of the 21 st century world economy and the concept of sustainable development, cooperation models within the helix and their evolution and the conditions of their functioning. It was also necessary to examine examples described in the literature of how these concepts are used as for the development of regions in Poland and other countries. The study has theoretical and reviewing character. To set forth the barriers which hinder the cooperation under the Quintuple Helix model in the world and in Poland, the results of research done by various authors were used in the scope of links between science, industry and government authorities. The knowledge and experience of scientists along with representatives of the cluster which builds such forms of cooperation in the West Pomeranian region were also taken into consideration.

\section{Regional innovative system and its participants}

P. Cooke is the author of the concept of regional innovation system. In the early $90 \mathrm{~s}$ of the twentieth century, he studied the conditions for innovations being created in the region. He assumed that they come into being as a result of interaction of various processes technological, social, institutional - which take place between regional entities from different fields. Innovation processes require cooperation, trust, communication and sharing knowledge, experience and competences (Cooke, 1992). In his concept, the regional innovation system is 
a collection of various entities which influence innovation processes in the region and the interactions between them. It is "a system of interactions between the sphere of science, $R \& D$, education system, finance and public authorities, fostering the processes of adaptation and collective learning" (Matusiak, 2005, p. 142). Production and service enterprises participate in innovation processes, together with universities, scientific and research units, research and development centres, support and knowledge transfer along with technology commercialization institutions, other business support organizations (such as local/regional entrepreneurship and innovation environment institutions) and regional government and self-governments. They join resources and enter into relationships and interactions in innovative projects.

Such conditions make possible interactive, trust-based learning of all partners, creation of new knowledge and technology, and then, their use for the needs of innovative solutions (Cooke et al., 1997; Cooke, 2001). Cooperation and interaction between participants in regional innovation processes also promote synergy of resources. They facilitate and accelerate the process of generating innovations, their putting into life and diffusion in the economy. They increase the innovativeness of small and medium enterprises. Public administration entities (which contribute to the regional innovation strategy) may play the function of the cooperation integrator within this system, along with clusters existing in the region, such as science and technology parks or industrial parks (Cooke, 2001; Dolińska, 2010). Some strong academic centres with the potential of knowledge, research and development (R\&D) background and the supply of technology sometimes initiate this cooperation. The regional innovation system contributes to an environment, fostering the generation and diffusion of innovation (Braczyk et al., 1998, Cooke, 1998). It has characteristic and region-specific economic, socio-cultural, technological, organizational, market and sometimes even legal features.

In modern times, it is currently emphasized that innovative processes take the form of networking activities in multidisciplinary teams (Łącka, 2013; Bojar, Machnik-Słomka, 2014, Szczepaniak, 2014; Puślecki, 2017) within regional innovative systems (Ranga, and Etzkowitz, 2013; Solesvik, 2017). The cooperation network joins partners from various areas of the economy who/which have diverse resources of knowledge and experience. Enterprises' clients, competitors, consultants, market analysts, along with knowledge users and creators who offer solutions made available within open innovation resources (Chesbrough, 2006) constitute the participants of the network, and at the same time, the source of innovation. Examples of open innovation successes are the achievements of virtual teams that draw up information for Wikipedia, a network of hobbyist programmers who generate Linux software or the implementation of corporate innovations suggested by clients, as in the case of My Starbucks Idea (Fournier, 2019).

Innovation network partners share the existent knowledge, jointly generate new knowledge and turn it into new technical or organizational solutions. Then, they transfer it to the economy in the form of product, process, and organizational innovations, etc. The cooperation makes 
easier the access to funds from various sources for risky innovative ventures. It also allows to share the costs of innovative projects and the risk of their failure between partners. It facilitates the access to new markets and technologies. The network contributes to opportunities for faster introduction of new solutions on the market, as well as for finding cross-sectoral innovations. As a result, it is possible to solve specific problems in macroscale, mesoscale and microscale in a completely new manner. In consequence, it helps to satisfy the current and future needs of the society.

\section{Challenges of the modern world economy at the beginning of the third decade of the 21 st century}

For some time, social disapproval has been revealed of the existence of humanity in present mechanisms of social and economic development (Giddings et al., 2002; IPCC, 2018, Grooten, and Almond, 2018) - more and more frequently in the international forum (e.g. United Nations, European Union, International Team for Climate Change), in the world of science, in the media, and even in the form of social protests. However, to change them, it requires the principles of sustainable development to be accepted by all countries and their residents. Since the 90 s of the twentieth century already, attempts have been made to convince politicians and societies of highly developed and developing countries to put these assumptions into life without much success. In 1992, after the Earth Summit in Rio de Janeiro, the United Nations Framework Convention on Climate Change and Action Programme were published. The UN Convention is an international treaty that sets out the assumptions for the international cooperation on the reduction in greenhouse gas emissions responsible for global warming. As to the Action Programme 21, it sets out the objectives of environmental protection in the 21 st century and presents the manner to develop and implement sustainable development programmes in local life. However, this has not had a sufficient impact to change the orientation and principles of human socio-economic development for over 25 years.

In the second decade of the 21 st century, ecologists, representatives of international political organizations and many inhabitants of various countries became more aware of the threats to the future of man on Earth. The recent several decades of much faster rate of economic growth have brought about disorder in the relations between man and the natural environment. This had devastating consequences for the biosphere and the opportunities for civilization's development. A. Skowroński understands the sources of ecological threats and civilization barriers as the uncontrolled wish and aspiration of the man to "satisfy new civilization needs to the detriment of biological and social needs, while reducing financial outlays to a minimum" (Skowroński, 2006, p. 50). Such a conduct has brought about threats to the natural environment, living conditions and management in the current period, exposing the man to health problems 
or even death. The prospects for the existence and socio-economic development of subsequent generations have weakened to a great extent. Some scientists (e.g. Zalasiewicz et al.; Bińczyk) put forward the thesis that since the 1950s the actions of humanity have contributed to changing the geological epoch from the Holocene to Anthropocene, i.e. the human epoch (Zalasiewicz et al., 2017; Bińczyk, 2018).

In the 21st century, environmental hazards and in consequence barriers to economic development do not make up the only challenges facing humanity. J. Martin, who studies the impact of technology on the society, believes that the latter is currently at a turning point and lives in a world of extremes - richness and poverty, overabundance of technology, globalization. People shall learn to manage these extremes and find solutions to the problems and conflicts they cause - with the use of cooperation, knowledge and innovations. J. Martin pointed out in his book more than ten challenges for the world economy in the current century, which determine the present and future lives of people on Earth (Martin, 2007). The following make them up:

- necessity to protect the Earth against climate threats (global warming);

- protecting the biosphere and biodiversity;

- reducing and solving the global problem of poverty with the help of the principles of sustainable development, innovation, political impact, but also personal acting in a regional and local scale;

- stabilizing growth rate of the global population, which requires education and raising women's awareness, along with economic growth in developing countries;

- adopting by societies of highly developed countries and those, aspiring to be developed, a sustainable lifestyle that does not burden the natural environment;

- achieving a fairer distribution of globalization costs and benefits - the planet has been becoming a global village, but not all of us benefit equally from globalization; costs are charging more undeveloped countries;

- preventing a total war with the use of extremely dangerous nuclear and biological weapons;

- counteracting terrorism by doing away with the reasons that entice people to terrorism; we need to find ways to reduce poverty, income polarization and exclusion in the world, together with improving conditions and quality of life (access to education, health protection, civic freedoms), establishing cooperation between people of diverse cultures, increasing tolerance to cultural, racial and religious differences;

- supporting creativity and entrepreneurship amongst the population - this will contribute to the creation of new jobs in traditional and new branches, new supply chains and enterprises based on ICT technologies and cooperation networks will appear;

- preventing the rapid spread of infectious diseases (pandemics) that could kill many millions of people (such cases have already occurred many times in history); 
- increasing human potential - discovering, strengthening and developing the hidden abilities of the population through advanced technologies that accelerate the ability to learn;

- developing artificial intelligence and proper management of this resource so as to serve humanity and not to dominate it;

- preventing a threat to human existence on Earth, if any, due to the release of a dangerous genetically modified pathogen;

- introducting transhumanism - in the 21 st century, we may be able to change people drastically through the use of neurotechnology, biotechnology and nanotechnology applied so as to reduce human limitations, improve human potential and condition (genetic modifications, implants of a different type than earlier, extending life by medical procedures unknown earlier); this idea is thought to be very controversial and raises many ethical concerns, although there are those who believe that it can help to build a civilization more advanced than ours;

- planning advanced civilization and the role of the man in a world without work - sooner or later machines will do almost all jobs and there will be a significant increase in real wealth; questions about the future are about what to do with the activity of people who have too much free time; these problems will increase with the development of both artificial intelligence and the phenomenon of transhumanism;

- modeling planet systems - in a situation where there is no way to turn back the effects of global warming, new science on the Earth system must be generated; changes occurring therein need to be monitored for the humanity to be able to control the condition of the planet, to take care of safe living and farming conditions in the long run;

- filling in the gap between technological skills and the common sense of their use; science and technology are developing very quickly, but the abilities of humanity to use them in a wise, prudent and effective way are insufficient; people have no deeper reflection on future living conditions; they focused on the growing pace of economic growth and on achieving consumption of unlimited level which in the case of least developed countries shall be at least growing.

J. Martin's thoughts refer to challenges in the megascale. However, we need to bear in mind the fact that each of them has and will have its consequences also in macro, meso and micro scales. This brings about such an effect that all phenomena, challenges, risks and opportunities shown above must be considered also in the context of the development of Poland, its regions, local communities and individual business entities. Innovative solutions to the problems and challenges identified above come into being and will occur in regional innovative systems, which mean in the framework of associations between five areas: science, industry, administration, civil society and the natural environment. The concept of their relationships and interactions is shown by the Quintuple Helix model. 


\section{Quintuple Helix Model - theoretical bases}

Long-term research on cooperation in regional innovative systems conducted by H. Etzkowitz and L. Leyesdorff (1995; 1998), L. Leydesdorff (1997; 2000), EG Carayannis and D. Campbell (2009; 2010), as well as EG Carayannis et al. (2012) first led to the creation of triple, quadruple and finally Quintuple Helix models. They were the subject of further research on the effects of applying these concepts in practice in various countries and regions (among other authors: Saad, 2004; Saad, and Zawdie, 2011; Arnikl et al., 2010; Ranga, and Etzkowitz, 2013; Grundel, and Dahlström, 2016; Sunina, and Rivza, 2016; Provenzano et al., 2016). The original model of cooperation between universities, enterprises and public administration (Triple Helix Model) has evolved into more elaborate concepts, increasingly embedded in the conditions of the changing world and the challenges it faces (Carayannis, and Campbell, 2010; 2012; Leydesdorff, 2012; Carayannis et al., 2018).

The original concept of the triple helix (in particular its hybrid version) indicated that regional innovative cooperation takes place between entities, belonging at the same time to three areas, or else; the world of science and education, the sector of enterprises and the institutions of government and innovation support (Razak, and White, 2015). Another element of the regional innovation system has been introduced in the Quadruple Helix Model. It is the civil society together with the media, which the latter uses and creates knowledge and it functions on the principles of democracy.

The Quintuple Helix Model is currently the most developed concept of cooperation between regional partners, originating from five areas (systems, circles, helices) of the innovative environment. It includes both the four areas of the regional innovation system recognized earlier (science and education, the economy, political-and- institutional, and socio-cultural areas) as well as the natural environment in which the society lives. According to the authors of this concept (E.G. Carayannis and D.J. Campbell), currently, the latter area forms the framework for the operation of the entire regional innovation system and gives the directions for the sustainable development in the knowledge-based economy.

Such an approach to innovative processes points to the changes of roles and tasks to be carried out by representatives of all subsystems of the regional innovation system in the recent thirty years (Etzkowitz, and Klofsten, 2005). Additionally, dynamic changes in the global economy which lay down contemporary development challenges had an impact thereon. In the light of these terms, the interpenetration of five areas (helixes) fosters coming into being of eco-innovation (ecological innovations, "green" innovations) and eco-entrepreneurship (entrepreneurial business whose base is the manufacture of environmental-friendly products and services). By the same, new manners of solving economic problems (sustainable economic growth, sustainable consumption), social issues (poverty, exclusion, inequalities), technological matters (development of technology and its reasonable use) and ecological 
problems (reducing the rate of destroying the natural environment and global warming effects for future generations, improvement in the quality of life).

In the Quintuple Helix Model, participants of innovation processes fulfil their traditional and new roles. Entities of the science and education system (universities, scientific and research institutes, public and private research and development centres and educational institutions) put into life educational, research and advisory tasks and deal with the transfer and commercialization of knowledge and technology. They educate the staff to work in the economy, contribute to improving and upgrading the qualifications of human resources in the region through lifelong learning (building human capital). They conduct scientific (basic, applied), research and development work on their own or with enterprises. They sometimes even test new solutions on a semi-industrial scale. Research results can be commercialized in numerous manners, by selling intellectual or industrial property rights to entrepreneurs. With the intermediary of academic entrepreneurship entities (spin-off firms), they create new solutions on their basis and introduce them to the market. Apart from that, they run innovation transfer centres, technology and entrepreneurship incubators. The participation of the university education branch in the region goes beyond the tasks covered by the original concepts of cooperation between science and the economy. A similar situation applies to entities from the area of industry.

Entrepreneurs, that represent manufacturing and servicing (economic) system compete for clients. To win with competitors, they report a demand for knowledge and new solutions (with reference to products, processes, organization and marketing) and create new demands in the society. Entrepreneurs create and implement innovations on the market, which facilitates their diffusion. As part of their core business (manufacturing and selling products along with services to the market), they cooperate with other enterprises. Innovative entrepreneurs increase the quality of regional human capital with the help of training, internships and staff exchange between the areas of science and business. They also start the cooperation with other regional stakeholders; the local government units and non-governmental organizations included. They provide jobs, whose number grows together with the demand for the increased innovations. The involvement of entrepreneurs caused by external effects (spillover effect) or multiplier effect has a positive impact on entrepreneurship in the region and its economic growth. Owing to them, entrepreneurs, creating new high tech firms can avail themselves of the offer of financial capital for innovations within venture capital and business angel funds as well as organizational support and consulting.

The group of entities included in the political and institutional subsystem of the Quintuple Helix Model encompasses local and regional authorities and business environment organizations. The public administration generates regional innovation strategies, principles for economic and innovation policy at a given level of regulation. It finances from public funds innovative procedures carried out by various participants of innovative processes and their teams (a system of grants, subsidies and subventions). Local self-government units shape and 
put into life the economic policy intended to maintain or increase the rate of economic growth and accelerate the development of the region. Simultaneously, innovation policy is the result of interaction between model stakeholders and not a strategy of conduct imposed by the authorities. Administration representatives initiate and supervise procedures related to the introduction of sustainable development principles, for instance related to renewable energy sources, reduction of exhaust emissions and preservation of biodiversity (ecological aspects), introduction of social innovations (for instance new models of taking care and support, promotion of the idea of sharing economy) so as to reduce the exclusion of the old, the disabled or to lower the use of resources, coming from production factors. In these actions, they cooperate both with institutions, supporting innovation and entrepreneurship, as well as representatives of other subsystems of the regional innovation system.

The fourth helix of the Quintuple Helix Model consists of civil society (socio-cultural subsystem). It encompasses those residing in the region, potential buyers and authors of innovations, and at the same time their reviewers. They play a completely different role in this model than before - being not only suppliers of the resources of production factors and consumers of products and services manufactured. They are also initiators of changes in manufacturing (due to new needs, tastes, changes in attitudes towards the world and nature) and report the demand for new solutions. They sometimes participate in the innovation process at the stage of testing the expectations for new solutions, testing new products, and even creating innovations as part of competitions announced by enterprises, universities or local selfgovernments. In this case, they participate in open innovation or user driven innovation actions. In the Quintuple helix model, those residing in the region are treated as a community aware of their rights and obligations, responsible for the region and their future. This community is strengthened by non-governmental organizations that put into life social economy tasks in the conditions of sustainable development.

The media, on the other hand, play an auxiliary function as they support the creation of a cultural and social aspect of innovation. They emphasize the attitudes and beliefs of individuals and social groups on the world, economy and society, innovations introduced and their consequences. The mass media present the results of debates on political, economic, environmental, social, cultural and religious issues that are important for civil society. They are in a position to change civil society's attitudes towards various issues, but also have an impact on entrepreneurs and the sphere of regulation.

Representatives of civil society are characterized by readiness to cooperate in the name of the common good, by creativity, trust, responsibility for themselves and the community (now and in the future), a tendency to sacrifice and to perceive their place in a wider context (for instance national, European and/or global). A community of such features grants good bases to build the social capital necessary for efficiently functioning innovative systems. 
The last element of the Quintuple Helix Model is the area of the natural environment, the so-called ecosystem within which all the aforementioned segments of the regional innovation system operate along with the model of E.G. Carayannis and D.F.J. Campbell (Carayannis et al., 2018). The challenges of the modern world discussed in the study, which result from the disrupted relations between the man and the environment, decide upon the direction of new solutions so as to create conditions for sustainable development. They shall serve both to reduce the harmfulness of production and consumption to the natural environment, along with the appropriate management of natural resources in order to improve the quality of life of the present population and to ensure living conditions to future generations. However, this requires a profound transformation of civil society, which shall accept development restrictions inherent in the natural environment and agree to achieve prosperity within the concept of sustainable development. T.D. Barth referred to this lifestyle as a new green lifestyle (Barth, 2011).

In consequence of all five model areas overlapping, a co-opetitive spatial and sectoral fractal innovation entrepreneurial ecosystem is created in the region (having features of both cooperation and competition). Its existence contributes to an enormous innovative potential of the region and its entities.

\section{Barriers to the implementation of the Quintuple Helix model in Polish regions}

Following the results of having analysed numerous research works related to problems while implementing helix models in different countries of various levels of development (among others Bloeden, and Stokes, 1994; Martin, 2000; Nieminen, and Kaukonen, 2001; Sutz, 2000; De Mello, and Etzkowitz, 2008; Dzisah, 2011; Rivera, 2011; Irawati, 2011; Ranga, and Etzkowitz, 2011, Łącka, 2011; 2013; Sieniawska, 2014; Razak, and White, 2015) and the experience of the members of the board of the 'Green Chemistry' West Pomeranian Chemical Cluster, we can claim that they are the resultant of barriers and difficulties revealed in all the discussed segments of the Quintuple Helix Models.

Similar problems may show in the case of this model implementation in Polish regions. The experience in the case of countries which use this model in practice indicates that difficulties in its putting into life are often combined together. They can be seen in the area of permanent and lasting relations being formed between those taking part in innovative processes, putting into life innovative business and technology commercialization by universities and enterprises. They happen, owing to too small involvement of self-governments along with the institutions of innovation environment and technology transfer in building together an environment to foster implementing of innovation. They can be seen when organizing 
financing for high risk ventures. Difficulties in cooperation are displayed in insufficient development of civil society and low level of social capital, improper or wrongly implemented innovation and environmental policy.

We could also sort out these barriers, by ascribing them to one of several groups; structural, system, awareness-cultural and competence restrictions. The first group of barriers originates from specific features of economy branches, meaning; industry and services, science, education and research branches, public administration and business environment organizations, together with non-governmental organizations. This group of barriers incorporates difficulties in initiating innovative projects in the region in consequence of the weak demand both for innovation and the technological offer of institutions of the regional science and research branch. No demand for new solutions indicates that companies compete primarily with the help of application of low prices of a product or service. This may come from the fact that the region features low economic growth, high unemployment and low income of buyers. Furthermore, the structure of the regional economy and the low technological level of its enterprises have an impact on it as well as too small development of entrepreneurship.

Other structural barriers are insufficient private and public outlays on research and development (R\&D), problems to find external sources for their financing, and so on. These barriers may also originate from too low supply of new solutions from regional universities and research institutes, and sometimes this supply not being matched to the demand of enterprises. In consequence, for instance, the entrepreneurs tend to avail themselves of technological offers developed in countries considered to be more innovative. The features characteristic for regional stakeholders contribute to problems while contacting and communicating between branches. This is not facilitated by differences of culture. The difficulties are made more persistent by insufficient support for lasting and multilateral ties between partners in the region and missing developed strategies or introduced economic and innovative (national, regional, local) policies.

System barriers are made up primarily by excessive regulatory activity and red tape along with too complicated legal provisions. These factors slow down quite effectively the tendency to make innovations within cooperation between various entities. In Poland, this is particularly visible in the case of owners of small and medium-sized enterprises and scientists, who evaluate adversely the scale of red tape while starting technological cooperation in projects co-financed from public funds. In the case of local self-governments, barriers which hinder engaging entrepreneurs, scientists and citizens to cooperate in the Quintuple Helix Models are also: short-term budgets and project planning horizons, poor incentives to innovation, low risk tendency of representatives of these institutions and no capacity to evaluate and manage risk in this type of projects, no knowledge on challenges before the region, too little orienting as to future needs of the regional community and no ability to engage innovation users into regional innovation processes (Arnikl et al., 2010; Nowakowska, 2010). 
The group of awareness-and-cultural barriers is made up by those factors that decide upon social and interpersonal relations between scientists, entrepreneurs, representatives of authorities, population, media and the natural environment. In Poland, no confidence in relations between people, of the state and the citizens and of the citizens and the state and its policy are particularly emphasized, along with the reluctance to get engaged in the democratization processes. It results from the research that Polish society still succumbs to stereotypes (for instance in relations between a scientist and an entrepreneur, a Pole and a foreigner, an immigrant). This has an adverse impact on building civil society. In most Polish regions, especially with a lower development rate, low awareness and low social acceptance of entrepreneurial attitudes, innovative activities and care for the biosphere are still visible.

The incentive to change the principles of managing natural resources and protect the natural environment makes the inhabitants of Polish regions aware with great difficulty. In this situation, the Quintuple Helix Model, which settles all innovative and business actions in the context of sustainable development and the natural environmental protection, does not find a wide support. Neither does foster it the policy of central authorities, which denies the problem of climate change being important. It seems that for the Polish authorities, the challenges of the $21^{\text {st }}$ century world economy, discussed in the study, are not currently the prevailing issues to be examined as soon as possible. These problems are neglected or used for propaganda purposes (for instance the unrealistic promise to produce 1 million electric cars in Poland in a few years), in spite of the clear symptoms of problems occurrence (for instance air pollution and smog in Polish cities, reduced water resources, decreasing biodiversity, stagnation in the development of renewable energy sources, middle income trap, reduced competitiveness of the economy).

The last category of difficulties in building and using the Quintuple Helix Model in Polish regions are competence barriers, which in the opinion of scientists and experts relate to all institutions and organizations of the regional innovation system. According to B. Sieniawska who cites the experts of the Polish Agency for Enterprise Development (PARP) who prepared "Recommendations for changes in Polish technology transfer and knowledge commercialization system" (Matusiak, and Guliński, 2010), they are "referred to public administration, authorities and universities administration, entrepreneurs as well as human resources division and management boards of support institutions. The issues of access to public aid, intellectual property, pro-innovative services and new streams of financial support are often beyond the competences of stakeholders in the technology transfer and knowledge commercialization system" (Sieniawska, 2014, p. 273). These comments relate to many aspects of the processes and their detailed examples can be found in the studies mentioned, by foreign authors included. And although almost ten years have passed since the PARP experts drew up their paper, members of the Board of the Green Chemistry West Pomeranian Chemical Cluster and scientists, cooperating therewith, while implementing innovative projects, confirm their occurrence. However, they believe that now, these barriers are of lesser importance than earlier. 


\section{Summary}

In the second decade of the 21 st century, Polish regions face many challenges present in the global economy. They set out their development opportunities and competitiveness now and in the future. The globalization, socio-demographic changes, climate threats, a knowledge-based economy, increasingly faster technological progress and its effects, energy problems, and finally the need to implement the principles of sustainable development, are contemporary determinants to select directions for the development of regions in highly developed countries in Europe. To find answers to these challenges, it is necessary to use the basic resources of economy which means the knowledge-based economy, technology, innovation and the ability of various partners in the region to cooperate in the innovation processes. This is fostered by an efficiently operating organized network of regional innovation system. It supports the creation of new solutions in the area of products, processes, organization, marketing, ecology or social matters by participants of innovative processes. Its core is made up by permanent and multilateral connections, the cooperation and interactions between several areas: science and research, manufacturing and servicing, institutional, socio-cultural and environmental subsystems. The dynamics of innovative processes in the region and its competitiveness in the context of the challenges of the 21 st century global economy are under the impact of their effectiveness.

Contemporary concepts with regard to cooperation within regional innovation processes are based on helix models. The Quintuple Helix model is the latest and most comprehensive model, good to comprehend present and future development conditions. It forms a framework to scientists, entrepreneurs, public administration institutions and business environment organizations to cooperate in a knowledge-based economy and subject to more and more pressure from the challenges discussed. It also emphasizes the need to include civil society and the media in actions to increase the region's innovativeness and to create conditions for sustainable development in micro-, meso-, macro- and mega- scales. However, this requires to perceive innovative processes in the context of the society's impact on the natural environment, interpersonal relations, social positions and standards, and on the selection of mechanisms for long-term socio-economic development.

In highly developed countries (European innovation leaders included), this idea is not only the object of research by theoreticians, but it also makes up a practical tool to improve the innovativeness and the competitiveness of regions in conditions of sustainable development. Theoretical and empirical research conducted helps to gather and develop knowledge on regional development factors in this helix model and to pass it on to practitioners. This allows to reduce the barriers to implement this type of cooperation and to achieve better effectiveness of links between the sphere of science, industry, the institutional environment and civil society while forming the bases for sustainable development. 
In Poland, the Quintuple Helix model has not been commonly known, yet. Few scientists undertake this type of interdisciplinary research. It is also difficult to find examples of its application in Polish regions. This is the consequence of the existing numerous barriers to such cooperation that can be found in all elements of the model. In Polish reality, the factors that limit regional cooperation in the area of innovation and entrepreneurship in the conditions of sustainable development can be grouped into the following categories: structural, system, awareness-cultural and competence ones. In many scientific studies that focus on the low level of innovation of the Polish economy and the cooperation of the science branch with other partners, the reasons for insufficient and weak links between science, the economy and society can be found. A major obstacle to the implementation of the Quintuple Helix model in Polish regions is also the un-developed civil society. The State's economic and innovation policy does not facilitate the dissemination of the Quintuple Helix model of cooperation in practice. Authors indicate that the regional and local authorities had better intensified their actions so as to form independent regional innovation policy, responding to the challenges of our times. This shall be focused on supporting multi-stakeholder undertakings, relying on the cooperation of a network of partners, including citizens, NGOs, representatives of the media, the world of culture, and so on.

The occurrence of so many barriers to hinder the co-operation in regional innovative systems in the Quintuple Helix model points to the further research being needed in this area. They shall focus on drawing up the framework for such co-operation in Polish socio-economic reality, laying down the conditions for its application in specific conditions of individual regions, evaluation principles and methods for measuring the effectiveness of innovative co-operation in the region and for individual stakeholders of innovative processes. The knowledge gathered in this field will be of importance to the theory of regional development, the theory of innovation, helix models, but will also help to persuade regional stakeholders to apply this model in practice.

\section{References}

1. Arnikil, R., Järvensivu, A., Koski, P., and Piirainen, T. (2010). Exploring the Quadruple Helix. Outlining user-oriented innovation models. Final Report of Quadruple Helix Research for CLIQ Project University of Tampere. Work Paper, 85.

2. Baccarne, B., Logghe, S., Schuurman, D., and De Marez, L. (2016). Socio-Ecological Entrepreneurship. Technology Innovation Management Review, 6, 3, 22-30.

3. Barth, T.D. (2011). The idea of a green new deal in a Quintuple helix Model of knowledge, know-how and innovation. International Journal of Social Ecology and Sustainable Development, 1, 2, 1-14. 
4. Binczyk, E. (2018). Epoka człowieka. Retoryka i marazm antropocenu. Warszawa: PWN.

5. Bloedon, R.V., and Stokes, D.R. (1994). Making university/industry collaborative research succeed. Research-Technology Management, 37, 2, 44-48.

6. Bojar, M., and Machnik-Słomka, J. (2014). Model potrójnej i poczwórnej helisy w budowaniu współpracy sieciowej dla rozwoju innowacyjnych projektów regionalnych. Zeszyty Naukowe Politechniki Ślaskiej. Seria: Organizacja i Zarządzanie, 76, 99-111.

7. Carayannis, E.G., and Campbell, D.F.J. (2010). Triple Helix, Quadruple Helix and Quintuple Helix and how do knowledge, innovation and the environment relate to each other? A proposed framework for a trans-disciplinary analysis of sustainable development and social ecology. International Journal of Social Ecology and Sustainable Development, 1(1), 41-69. Retrieved from http: //www.igi-global.com/bookstore/article.aspx?titleid= 41959, 12.09.2019.

8. Carayannis, E.G., and Campbell, D.F.J. (2009). 'Mode 3' and 'Quadruple Helix': Toward a 21 st century fractal innovation ecosystem. International Journal of Technology Management, 46, 3/4, 201-234.

9. Carayannis, E.G., Grigoroudis, E., Campbell, D.F.J., Meissner, D., and Stamati, D. (2018). The ecosystem as helix: an exploratory theory-building study of regional co-opetitive entrepreneurial ecosystems as Quadruple/Quintuple Helix Innovation Models. $R \& D$ Management, 48, 1, 148-162.

10. Carrayanis, E.G., and Campbell, D.F.J. (2014). Developed democracies versus emerging autocracies: art, democracy, and innovation in Quadruple Helix innovation systems. Journal of Innovation and Entrepreneurship, 3:12. Retrieved from http://www.innovationentrepreneurship.co/content/3/1/12, 29.08.2019.

11. Carrayanis, E.G., Barth, T.D., and Campbell, D.F.J. (2012). The Quintuple Helix innovation model: global warming as a challenge and driver for innovation. Journal of Innovation and Entrepreneurship, 1:2. Retrieved from http://www.innovation-entrepreneurship.co/ content/1/1/2, 28.08.2019.

12. Chesbrough, H.W. (2006). Open Innovation: The New Imperative for Creating and Profiting from Technology. Boston: Harvard Business School Press.

13. Cooke, P. (1992). Regional Innovation System: Competitive Regulation in the New Europe. Geoforum, 23, 365-382.

14. Cooke, P. (1998). Introduction: origins of the concept. In: H-J. Braczyk, P. Cooke, and M. Heidenreich (Eds.), Regional Innovation Systems: The role of governances in a globalized world (pp. 2-25). London: UCL Press.

15. Cooke, P. (2001). Regional Innovation Systems, Clusters and the Knowledge Economy. Industrial and Corporate Change, 10, 4, 945-974.

16. Cooke, P., Uranga, M.G., Etxebarria, G. (1997). Regional innovation systems: Institutional and organisational dimensions. Research Policy, 26, 4-5, 475-491. 
17. De Mello, J.M.C., and Etzkowitz, H. (2008). New directions in Latin American universityindustry-government interactions. International Journal of Technology Management and Sustainable Development, 7, 3, 193-204.

18. Dolińska, M. (2010). Innowacje w gospodarce oparte na wiedzy. Warszawa: PWE.

19. Dzisah, J. (2011). Mobilizing for development: putting the Triple Helix into action in Ghana. In: M. Saad, and G. Zawdie (Eds.), Theory and Practice of Triple Helix Model in Developing Countries: Issues and Challenges (pp. 146-160). New York: Routledge.

20. Etzkowitz, H., and Klofsten, M. (2005). The innovating region: toward of theory of knowledge-based regional development. $R \& D$ Management, 35, 3, 243-255.

21. Etzkowitz, H., and Leydesdorff, L. (1995). The Triple Helix: University-IndustryGovernment Relations: A Laboratory for Knowledge-Based Economic Development. EASST Review, 14, 14-19.

22. Etzkowitz, H., and Leydesdorff, L. (1998). The Triple Helix as a model for innovation studies. Science and Public Policy, 25, 195-2013.

23. Fournier, A. (2019). My Starbucks Idea: an Open Innovation Case-Study. Retrieved from https://www.braineet.com/blog/my-starbucks-idea-case-study/, 1.09.2019.

24. Giddings, B., Hopwood, B., and Brien, G.O. (2002). Environment, economy and society: Fitting them together into sustainable development. Sustainable Development, 10, 4, 187-196.

25. Grooten, M., and Almond, R.E.A. (Eds.) (2018). Living Planet Report - 2018, WWF, Switzerland: Gland.

26. Grundel, I., and Dahlström, M. (2016). A Quadruple and Quintuple Helix Approach to Regional Innovation Systems in the Transformation to a Forestry-Based Bioeconomy. Journal Knowledge Economy, 7, 963-983.

27. IPCC (2018). Global Warming of $1.5^{\circ} \mathrm{C}$. An IPCC Special Report on the impacts of global warming of $1.5^{\circ} \mathrm{C}$ above pre-industrial levels and related global greenhouse gas emission pathways, in the context of strengthening the global response to the threat of climate change, sustainable development, and efforts to eradicate poverty. Geneva, Switzerland: World Meteorological Organization.

28. Irawati, D. (2011). Bridging the gaps in the Triple Helix: A demand or a challenge for Indonesian case study? In: M. Saad, and G. Zawdie (Eds.), Theory and Practice of Triple Helix Model in Developing Countries: Issues and Challenges (pp. 161-175). New York: Routledge.

29. Kimatu, J.N. (2016). Evolution of strategic interactions from the triple to quad helix innovation models for sustainable development in the era of globalization. Journal of Innovation and Entrepreneurship, 5:16, DOI: 10.1186/s13731-016-0044-x.

30. Kondratiuk-Nierodzińska, M. (2013). Regionalne systemy innowacji a konkurencyjność województw w Polsce. Białystok: Wydawnictwo Uniwersytetu w Białymstoku. 
31. Łącka, I. (2011). Wspótpraca technologiczna polskich instytucji naukowych i badawczych z przedsiębiorstwami jako czynnik wzrostu innowacyjności polskiej gospodarki. Szczecin: Wydawnictwo Uczelniane Zachodniopomorskiego Uniwersytetu Technologicznego.

32. Łącka, I. (2013). Efektywność powiąań nauki z przemysłem w procesach innowacyjnych. Szczecin: Stowarzyszenie Naukowe Instytut Gospodarki i Rynku.

33. Leydesdorff, L. (1997). The new communication regime of university-industrygovernment relations. In: H. Etzkowitz, and L. Leydesdorff (Eds.), Universities and the Global Knowledge Economy: A Triple Helix of University-Industry-Government Relations. London: Cassel Academic.

34. Leydesorff, L. (2000). The Triple Helix: an evolutionary model of innovations. Research Policy, 29, 2, 243-255.

35. Leydesorff, L. (2012). The Triple Helix, Quadruple Helix, ..., and an N-tuple of Helices: Explanatory Models for Analyzing the Knowledge-based Economy? Journal of the Knowledge Economy, 3, 1, 25-35.

36. Marszowski, R. (2019). Innovation in the context of strengthening active social policy development and its importance for the process urban community organizing. Scientific Papers of the Silesian University of Technology. Organization and Management Series, 134, 153-170.

37. Martin, J. (2007). The Meaning of the 21st Century: A Vital Blueprint for Ensuring Our Future. New York: Riverhead Books.

38. Martin, M. (Ed.) (2000). The Management of University-industry Relations: Five Institutional Case Studies from Africa, Europe, Latin America and the Pacific Region. Paris: International Institute for Educational Planning, UNESCO.

39. Matusiak, K. (ed.) (2005). Innowacje i transfer technologii. Słownik pojęć. Warszawa: PARP.

40. Morawska-Jancelewicz, J. (2016). Innowacje społeczne w miastach europejskich. Przykłady dobrych praktyk. Studia Miejskie, 23, 65-79.

41. Nieminen, M., and Kaukonen, E. (2001). Universities and R\&D Networking in a knowledge-based economy. SITRA Reports Series, 11, Helsinki.

42. Nowakowska, A. (2010). Budowanie regionalnych systemów innowacji: polskie doświadczenia. Ekonomiczne Problemy Ustug, 48, 143-157.

43. Provenzano, V., Arnone, M., and Seminara, M.R. (2016). Innovation in the rural areas and the linkage with the Quintuple Helix Model. Procedia - Social and Behavioral Sciences, $223,442-447$.

44. Prystom, J. (2012). Innowacje w procesie rozwoju gospodarczego. Istota i uwarunkowania. Warszawa: Difin.

45. Puślecki, Z.W. (2017). Model potrójnej helisy (Triple Helix) we wzroście efektów innowacyjnych i konkurencyjności. Prace Naukowe Uniwersytetu Ekonomicznego we Wrocławiu, 475, 238-257. 
46. Ranga, M., and Etzkowitz, H. (2013). Triple Helix systems: an analytical framework for innovation policy and practice in the Knowledge Society. Industry \& Higher Education, 27, 3, 237-262.

47. Ranga, M., and Etzkowitz, H. (2011). Creative reconstruction: a Triple Helix-based Innovation strategy in Central and Eastern Europe Countries. In: M. Saad, and G. Zawdie (Eds.), Theory and Practice of Triple Helix Model in Developing Countries: Issues and Challenges (pp. 249-283). New York: Routledge.

48. Razak, A.A., and White, G.R.T. (2015). The Triple Helix model for innovation: a holistic exploration of barrier and enablers. International Journal of Business Performance and Supply Chain Modelling, 7, 3, 278-291.

49. Rivera, M. (2011). Innovation systems interactions and technology transfer and assimilation for industrial development: the cases of South Korea and Mexico. In: M. Saad, and G. Zawdie (Eds.), Theory and Practice of Triple Helix Model in Developing Countries: Issues and Challenges (pp. 25-51). New York: Routledge.

50. Saad, M. (2004). Issues and challenges arising from the application of innovation strategies based on the Triple Helix culture: experience of the incubation system in Algeria. International Journal of Technology Management and Sustainable Development, 3, 1, 17-35.

51. Saad, M., and Zawdie, G. (Eds.) (2011). Theory and Practice of Triple Helix Model in Developing Countries: Issues and Challenges. New York: Routledge.

52. Sieniawska, B. (2014). Trudności we współpracy uczelni z biznesem w zakresie komercjalizacji wiedzy w świetle badań naukowych. Studia Ekonomiczne. Uniwersytet Ekonomiczny w Katowicach, 199, 270-281.

53. Skowroński, A. (2006). Zrównoważony rozwój perspektywą dalszego postępu cywilizacyjnego. Problemy Ekorozwoju, 1, 2, 50.

54. Solesvik, M.Z. (2017). The Triple Helix model for regional development and innovation: context of Nordic countries. Forum Scientiae Oeconomia, 5, 4, 5-21.

55. Sunina, L., and Rivza, B. (2016). The Quintuple Helix Model: Way of Regional Development Centres in Latvia to Smart Public Administration. Research for Rural Development, 2, 135-142.

56. Sutz, J. (2000). The university-industry-government relations in Latin America. Research Policy, 29, 2, 279-290.

57. Szczepaniak, M. (2014). Znaczenie sieci współpracy w rozwoju innowacji społecznych. Zeszyty Naukowe Politechniki Śląskiej. Seria: Organizacja i Zarzadzanie, 76, 155-166.

58. Zalasiewicz, J., Waters, C., and Head, M.J. (2017). Anthropocene: its straigraphic basis. Nature, 541, 289. 